\title{
Blood lactate as a predictor of mortality in critically ill children
}

\author{
*Channanayaka Chandrashekar ${ }^{1}$, Monisha Prabhakar ${ }^{1}$, M Santhoshkumar ${ }^{1}$, Reddy K Harish $^{1}$
}

Sri Lanka Journal of Child Health, 2018; 47(1): 40-43

\begin{abstract}
Objective: To study blood lactate levels at admission in predicting mortality in critically ill children requiring haemodynamic / respiratory support.
\end{abstract}

Method: A prospective observational study was done in 200 critically ill admissions to the paediatric intensive care unit (PICU), requiring haemodynamic / respiratory support. The demographic data, clinical status, organ involvement and therapeutic interventions were recorded in a predesigned proforma until hospital discharge or death. Lactate levels were estimated at admission and were correlated with the mortality and organ dysfunction

Results: The geometric mean of lactate levels at admission in survivors and non survivors were $20.58 \mathrm{mg} / \mathrm{dl}$ and $50.48 \mathrm{mg} / \mathrm{dl}$ respectively. Blood lactate was $82.9 \%$ sensitive and $85.4 \%$ specific at the optimal cut-off value of $33.7 \mathrm{mg} / \mathrm{dl}$. The positive likelihood ratio was 5.67 and the negative likelihood ratio 0.2 .

Conclusions: Blood lactate levels at admission predict mortality in critically ill children requiring haemodynamic/respiratory support.

\section{DOI: http://dx.doi.org/10.4038/sljch.v47i1.8428}

(Keywords: Blood lactate, critically ill children, cut-off value, in-hospital mortality)

\section{Introduction}

Standard care is not well defined for paediatric critical care, as most protocols and practices in the paediatric intensive care unit (PICU) are actually extrapolated from adult critical care. Lactate is a marker of tissue hypoperfusion and cellular hypoxia and increased blood lactate levels are

\footnotetext{
$\overline{{ }^{1} J S S \text { University, JSS Medical College, Mysore, }}$ India

*Correspondence: chandruped@yahoo.co.in

(Received on 21 April 2017: Accepted after revision on 16 June 2017)

The authors declare that there are no conflicts of interest

Personal funding was used for the project.

Open Access Article published under the Creative

Commons Attribution CC-BY (CC)
}

significantly associated with mortality ${ }^{1-5}$. Past studies have assessed the predictive value for mortality of a single lactate screening measurement on admission and serial lactate measurements in adults $^{1,6}$. However, the predictive value of a single lactate estimation on admission is controversial in critically ill children ${ }^{7-9}$.

\section{Objective}

To study blood lactate levels at admission in predicting mortality in critically ill children requiring haemodynamic / respiratory support.

\section{Method}

This prospective observational study was conducted from January 2015 to July 2016 in the PICU, Department of Paediatrics at JSS Hospital, Mysore, India after due approval from the Institute Ethical Committee. Two hundred critically ill children from 1 month of age to 18 years of age requiring haemodynamic / respiratory support were chosen for the study. Children with trauma, postoperative cases and children with suspected disorders of lactate metabolism were excluded from the study.

After taking informed consent from the parents, using standard aseptic techniques, a sample of $2.5 \mathrm{ml}$ venous blood was taken from the critically ill children on admission to the PICU and lactate levels were measured using an autoanalyser. The levels were expressed in $\mathrm{mg} / \mathrm{dl}$. Clinical and laboratory data, collected on admission, comprised age, gender, diagnosis, blood tests, biochemical profile and arterial blood gas analysis. Clinical features, comorbidities and treatment received were recorded until either the child was discharged from hospital or died.

Presence of multi-organ dysfunction syndrome (MODS) during the hospital stay was determined using criteria modified from the International Paediatric Sepsis Consensus Conference ${ }^{10}$. Lactate levels on admission in children with dysfunction in 2 or more organs (multi-organ dysfunction) were compared to lactate levels of those with less than 2 dysfunctional organs. Data was subjected to statistical analysis through SPSS software. Continuous parameters were expressed as mean with standard deviation. A Receiver Operating Characteristic (ROC) curve was plotted to assess the predictive power of lactate levels at admission in predicting mortality in the critically ill children. 
A $p$ value $<0.05$ was considered statistically significant.

\section{Results}

Out of the 200 cases included in the study, the median age of the cases was 48 months with an inter quartile range between 12 months and 120 months. There were $115(57.5 \%)$ males and 85 $(42.5 \%)$ females. There were $48(24 \%)$ deaths. The mean lactate levels at admission in survivors and non-survivors were $23.79 \pm 12.76 \mathrm{mg} / \mathrm{dl}$ and 55.06 $\pm 21.88 \mathrm{mg} / \mathrm{dl}$ respectively (Table 1$)$.

Table 1: Mean lactate levels at admission in survivors vs non-survivors

\begin{tabular}{|l|c|c|c|}
\hline \multicolumn{1}{|c|}{ Outcome (Number) } & $\begin{array}{c}\text { Mean lactate level on admission } \\
\text { (mg/d) }\end{array}$ & Standard deviation & \multirow{2}{*}{$\boldsymbol{p}$ value } \\
\hline Survived (152) & 23.79 & 12.76 & $<0.001$ \\
\hline Died (48) & 55.06 & 21.88 & \\
\hline
\end{tabular}

The geometric means of lactate levels on admission in survivors and non survivors were $20.58 \mathrm{mg} / \mathrm{dl}$ and $50.48 \mathrm{mg} / \mathrm{dl}$ respectively. Deaths in critically ill children were significantly associated with increased blood lactate levels $(\mathrm{p}<0.001)$. Student's $\mathrm{t}$-test was the statistical test used for comparison.
Among the 200 children, $61(30.5 \%)$ had lactate levels $<20 \mathrm{mg} / \mathrm{dl}$ and $94(47 \%), 23(11.5 \%), 13$ $(6.5 \%), 08(4 \%)$ and $01(0.5 \%)$ had lactate levels between $20-40 \mathrm{mg} / \mathrm{dl}, 41-60 \mathrm{mg} / \mathrm{dl}, 61-80 \mathrm{mg} / \mathrm{dl}$, $81-100 \mathrm{mg} / \mathrm{dl}$ and $>100 \mathrm{mg} / \mathrm{dl}$ respectively (Table 2).

Table 2: Comparison of outcome among study subjects with different blood lactate concentrations at admission

\begin{tabular}{|l|c|c|c|c|c|c|}
\hline $\begin{array}{c}\text { Lactate levels } \\
\text { (mg/dl) }\end{array}$ & Less than 20 & $\mathbf{2 1 - 4 0}$ & $\mathbf{4 1 - 6 0}$ & $\mathbf{6 1 - 8 0}$ & $\mathbf{8 1 - 1 0 0}$ & More than 100 \\
\hline Survived (152) & 59 & 82 & 07 & 04 & 0 & 0 \\
\hline Died (48) & 02 & 12 & 16 & 09 & 08 & 01 \\
\hline
\end{tabular}

At the cut-off value of $>20 \mathrm{mg} / \mathrm{dl}$, blood lactate displayed a sensitivity of $95.8 \%$ and a specificity of $63.4 \%$ for predicting in-hospital mortality. The specificity increased to $100 \%$ at the cut-off value of $>80 \mathrm{mg} / \mathrm{dl}$, although the sensitivity decreased to $18.75 \%$. Blood lactate displayed a sensitivity of
$82.9 \%$ and a specificity of $85.4 \%$ at the optimal cut-off value of $33.65 \mathrm{mg} / \mathrm{dl}$. The level of blood lactate was predictive of in-hospital mortality and achieved an area under curve (AUC) of $0.90 ;(95 \%$ CI, 0.858-0.957; $\mathrm{p}<0.001$ ) (Table 3).

Table 3: Predicting performance of admission blood lactate for in-hospital mortality

\begin{tabular}{|l|c|c|c|c|c|c|}
\hline & AUC & $\mathbf{9 5 \%}$ CI & $\boldsymbol{p}$ value & Optimal cut-off & Sensitivity & Specificity \\
\hline Blood lactate at admission & 0.90 & $0.858-0.957$ & $<0.001$ & $33.65(\mathrm{mg} / \mathrm{dl})$ & $82.9 \%$ & $85.4 \%$ \\
\hline
\end{tabular}

AUC: Area under curve; CI: confidence interval

The positive predictive value of the optimal cut off value of blood lactate at admission was $85.02 \%$ and the negative predictive value was $83.3 \%$. Positive likelihood ratio was 5.67 and negative likelihood ratio was 0.2 .
The most common organ dysfunction noticed in our study was cardiac dysfunction which occurred in $43 \%$ of the cases. Ninety two $(46 \%)$ cases had single organ dysfunction and $50(25 \%)$ cases had multiorgan failure. The incidence of MODS in critically ill children was also significantly associated with increased blood lactate levels $(\mathrm{p}<$ 0.01) (Table 4).

Table 4: Mean \& median lactate levels at admission in study subjects with single and multiorgan dysfunction

\begin{tabular}{|l|c|c|c|}
\hline Organ dysfunction & Nil & Single organ & Multiorgan \\
\hline Number (\%) & $57(28.5)$ & $93(46.5)$ & $50(25.0)$ \\
\hline Mean (mg/dl) & 26.16 & 30.02 & 39.54 \\
\hline Standard deviation (mg/dl) & 16.60 & 19.18 & 24.10 \\
\hline Median (mg/dl) & 24.00 & 27.00 & 32.40 \\
\hline
\end{tabular}

No organ $v$ s single organ $p=0.19 ;$ No organ vs. multiorgan $p=0.001$ Student's $t$-test was the statistical test used for comparison.

\section{Discussion}

Numerous studies have shown that both admission and peak lactate blood levels are associated with deaths in adults ${ }^{1,4,11,12}$. A study by Hatheril et al showed that blood lactate levels which were persistently raised more than $2 \mathrm{mmol} / \mathrm{L}$ after 24 hours were associated with a $93 \%$ mortality in comparison to $30 \%$ in those children whose lactate 
level had become normal ${ }^{7}$. Munde A et al in 2014 in Delhi observed that lactate clearance less than $30 \%$ at 6 hours after admission predicts deaths in PICU admissions ${ }^{13}$. The Paediatric Risk of Mortality (PRISM) score is one of the main indicators used in the paediatric intensive care unit. It was obtained and validated from the Physiologic Stability Index (PSI) score after eliminating the insignificant PSI reducing the number of physiological parameters, creating and validating the PRISM. It is a validated third generation pediatric physiology-based score for mortality risk. It uses 14 parameters (physiological and laboratory data) and for each one is used the highest severity value recorded in the first 24 hours. It presents an excellent discriminatory performance and prediction, being used in many PICUs as a prognostic score to assess gravity of disease. Past studies suggest that PRISM III can predict deaths and clinical outcomes in children ${ }^{14-16}$. The optimal cut-off level of lactate for predicting in-hospital mortality in critically ill children as per the study by Zhenjiang Bai et al was blood lactate level of $5.55 \mathrm{mmol} / 1$ (49.5 mg/dl), which had a sensitivity of $61 \%$ and a specificity of $86 \%{ }^{17}$. This study also compared the prognostic performance of a lactate value at admission to PRISM III score and found that the prognostic accuracy of blood lactate for inhospital mortality was similar to that of the PRISM III score. They recommended assessing mortality risk with blood lactate at admission as it is simple to use compared to PRISM scoring.

\section{Conclusions}

Blood lactate levels at admission predict mortality in critically ill children requiring haemodynamic/ respiratory support.

\section{References}

1. Kruse O, Grunnet N, Barfod C. Blood lactate as a predictor for in-hospital mortality in patients admitted acutely to hospital: a systematic review. Scandinavian Journal of Trauma, Resuscitation and Emergency Medicine 2011; 19: 74.

https://doi.org/10.1186/1757-7241-19-74

PMid: 22202128 PMCid: PMC3292838

2. Kang YR, Um SW, Koh WJ et al. Initial lactate level and mortality in septic shock patients with hepatic dysfunction. Anaesthesia and Intensive Care 2011; 39: 862-7.

PMid: 21970130

3. Nichol AD, Egi M, Pettila $V$ et al. Relative hyperlactatemia and hospital mortality in critically ill patients: a retrospective multi-centre study. Critical

Care 2010; 14: R25.

https://doi.org/10.1186/cc8888

PMid: 20181242 PMCid: PMC2875540

4. Martin J, Blobner M, Busch R et al. Pointof-care testing on admission to the intensive care unit: lactate and glucose independently predict mortality. Clinical Chemistry and Laboratory Medicine 2013; 51: 405-12.

https://doi.org/10.1515/cclm-2012-0258 PMid: 22987833

5. Jansen TC, van Bommel J, Bakker J. Blood lactate monitoring in critically ill patients: a systematic health technology assessment. Critical Care Medicine 2009; 37: 2827-39.

https://doi.org/10.1097/CCM.0b013e3181 a98899

PMid: 19707124

6. Juneja D, Singh O, Dang R. Admission hyperlactatemia: causes, incidence, and impact on outcome of patients admitted in a general medical intensive care unit. Journal of Critical Care 2011; 26: 316-20. https://doi.org/10.1016/j.jcrc.2010.11.009 PMid: 21255970

7. Hatherill M, McIntyre AG, Wattie M et al. Early hyperlactataemia in critically ill children. Intensive Care Medicine 2000; 26: 314-8.

https://doi.org/10.1007/s001340051155

PMid: 10823388

8. Morris KP, McShane P, Stickley J et al. The relationship between blood lactate concentration, the Paediatric Index of Mortality 2 (PIM2) and mortality in paediatric intensive care. Intensive Care Medicine 2012; 38: 2042-6.

https://doi.org/10.1007/s00134-012-27337

PMid: 23100008

9. Koliski A, Cat I, Giraldi DJ, Cat ML. Blood lactate concentration as prognostic marker in critically ill children. Journal of Pediatrics (Rio J) 2005; 81: 287-92. https://doi.org/10.2223/JPED.1364

10. Goldstein B, Giroir B, Randolph A. International pediatric sepsis consensus conference: definitions for sepsis and organ dysfunction in paediatrics. Pediatric Critical Care Medicine 2005; 6: 2-8. 
https://doi.org/10.1097/01.PCC.00001491 31.72248.E6

PMid: 15636651

11. Mikkelsen ME, Miltiades AN, Gaieski DF et al. Serum lactate is associated with mortality in severe sepsis independent of organ failure and shock. Critical Care Medicine 2009; 37: 1670-7.

https://doi.org/10.1097/CCM.0b013e3181 9fcf68

PMid: 19325467

12. Gustavsson L, Andersson LM, Brink M et al.Venous lactate levels can be used to identify patients with poor outcome following community-onset norovirus enteritis. Scandinavian Journal of Infectious Diseases 2012; 44: 782-7. https://doi.org/10.3109/00365548.2012.68 6671

PMid: 22831183

13. A Munde, N Kumar, RS Beri et al. Lactate Clearance as a Marker of Mortality in Pediatric Intensive Care Unit. Indian Pediatrics 2014; 51: 565-7. https://doi.org/10.1007/s13312-014-04482

PMid: 25031136

14. Tan GH, Tan TH, Goh DY et al. Risk factors for predicting mortality in a paediatric intensive care unit. Annals of the Academy of Medicine Singapore 1998; 27: 813-8.

PMid: 10101556
15. Brady AR, Harrison D, Black $S$ et al. Assessment and optimization of mortality prediction tools for admissions to paediatric intensive care in the United Kingdom. Pediatrics 2006; 117: e733e742.

https://doi.org/10.1542/peds.2005-1853

PMid: 16510615

16. Gemke RJ, van Vught J: Scoring systems in pediatric intensive care: PRISM III versus PIM. Intensive Care Medicine 2002; 28: 204-7. https://doi.org/10.1007/s00134-001-11852

PMid: 11907665

17. Zhenjiang Bai, Xueping Zhu, Mengxia L et al. Effectiveness of predicting inhospital mortality in critically ill children by assessing blood lactate levels at admission. BMC Pediatrics 2014; 14:83 https://doi.org/10.1186/1471-2431-14-83 PMid: 24673817 PMCid: PMC3976355 